\title{
Estimation of Nitrate and Phosphate Leaching from Lysimeter Simulation of Rice Straw Landfill Bioreactor and Evaluation of Fertilizer Quality of Resulting Compost
}

\author{
D.A.S. Gamage, S.S.R.M.D.H.R. Wijesekara ${ }^{1}$, G.W.N.L. Sarathchandra ${ }^{2}$ \\ B.F.A. Basnayake ${ }^{2 *}$ and W.A.J.M. Costa ${ }^{3}$ \\ Postgraduate Institute of Agriculture \\ University of Peradeniya \\ Sri Lanka
}

\begin{abstract}
Rice is the staple food in Sri Lanka where more than $40 \%$ of the farmers are engaged in paddy cultivation producing approximately 4.1 million metric tons of paddies. Cultivation of paddy results in almost the same quantity of rice straw annually out of which a very high proportion is wasted. Hence, there is an enormous potential of utilizing paddy straw for the production of quality compost using landfill bioreactors. In this context, the main objectives of the study were to design a lysimeter simulation of a landfill bioreactor to produce compost from anaerobic digestion using rice straw, animal and green manure and evaluate the quality of the resulting compost. A secondary objective was to minimize possible groundwater pollution with nitrate nitrogen, phosphate and reduce the BOD and COD levels resulting from direct dumping of straw. The lysimeter consisted of a liner made of claypolythene-clay, gas collection system, leachate recirculation system, and main reactor. Altogether $431 \mathrm{~kg}$ of straw, $26 \mathrm{~kg}$ of cow dung and $32 \mathrm{~kg}$ of Gliricidia were added to the main reactor. The lysimeter performances were evaluated by estimating $\mathrm{pH}$, nitrate nitrogen, phosphate contents, BOD and COD of both leachate and the permeate. After 200 days of operation, nitrate nitrogen and phosphate of the leak were $1.23 \mathrm{mg} / \mathrm{L}$ and $0.03 \mathrm{mg} / \mathrm{L}$, respectively. BOD increased during the first 14 days and it gradually decreased after 200 days. Quality of the compost is tallying with the Sri Lanka standards (SLS) guidelines. The study shows that there is a high potential of producing compost from landfill bioreactor using rice straw. It also revealed that the ground water pollution resulting from nitrate nitrogen and phosphate can significantly be mitigated. Further, it was observed that the levels of BOD and COD can also be reduced.
\end{abstract}

Key words: Bioreactor, BOD, COD, Compost, Lysimeter, Mitigation.

\section{INTRODUCTION}

Rice is the staple food for all Sri Lankans in the past, at present and in the future as well. Therefore, rice cultivation is the major agricultural activity of the country since ancient times. With the increase of population pressure, there is a need to increase the rice production in order to keep pace with the demand. Achieving a higher rice production

To whom correspondence should be addressed: benb@pdn.ac.lk

Chemical and Environmental Systems Modeling Laboratory, Institute of Fundamental Studies, Sri Lanka

Department of Agricultural Engineering, Faculty of Agriculture, University of Peradeniya, Peradeniya,

Sri Lanka

Department of Crop Science, Faculty of Agriculture, University of Peradeniya, Peradeniya, Sri Lanka 
through expansion of cultivable land is limited and hence the main possibility is to increase the yield per unit land area through better management practices, use of high yielding varieties and adaptation of new technology in rice cultivation.

Research shows that the majority of soils in main rice growing areas are low in organic matter (Wickramasinghe and Wijewardena, 2000). As a result, many soils found in Sri Lanka are low in cation exchange capacity. Cation exchange capacity levels in majority of soils is lower than $10 \mathrm{cmol} / \mathrm{kg}$ (Panabokke, 1996) and under such conditions, the retention of plant nutrients is low. In general, organic manure is useful in conserving soil fertility. As a result, seasonal application of available organic manure shows beneficial effects on crop growth as well as on overall soil fertility (Wickramasinghe and Wijewardena, 2003). Soil organic matter content is one of the key parameters which influences the soil fertility and productivity. However, it should be noted that increasing the organic matter content in soils is a difficult task due to prevailing high temperature in many parts of the country. In this regard, the seasonal application of organic materials is necessary. Rice straw, animal and green manure, city wastes, crop wastes. could be used as sources of organic manure to maintain the organic matter content in soil. Organic matter in manure can be a valuable environmental resource or an environmental pollutant if managed poorly. If manure is allowed to discharge to a water body or to run off from a land application site, the organic matter can become a harmful pollutant. Organic matter in the form of manure degrades rapidly and consumes considerable amounts of oxygen (often measured as biochemical oxygen demand, (BOD) or chemical oxygen demand (COD)). If this occurs in an aquatic environment, oxygen can quickly be depleted. Frequent fish deaths are partly attributed to low oxygen concentration (Brady, 2002).

The use of landfill bioreactors for treating municipal solid wastes is the most popular method to produce biogas in the world due to the easiness of the operation and maintenance (Warith et al., 2005), however, it is a new concept for treating agricultural wastes. Moreover, the landfill bioreactors show long term biogas production due to the natural balance occurring in the reactor. In addition, there is no unfavorable odour release by the landfill bioreactor as it is kept properly covered. Further, the landfill bioreactor can hold a large quantity of waste than other anaerobic digesters. One of the other main advantages of landfill bioreactors is that the resultant by-products can be utilized for organic fertilizer once the biogas generation ceases thereby reducing the environmental pollution caused by nitrate and phosphate. Furthermore, this also reduces BOD and COD levels of the effluent.

The concept of manufacturing compost using rice straw is practicable in Sri Lanka, where more than $40 \%$ of the farmers are engaged in paddy cultivation producing 4.1 million metric tons (Department of Census and Statistics, 2008) of paddy resulting almost the same amount of paddy straw annually (Champaign et al., 1999). Of the total paddy straw production, considerable amount is wasted. Hence, there is a great potential of using landfill bioreactors for production of high quality compost. In this context, the main objective of this study was to design and test a lysimeter simulation of a landfill bioreactor for compost production using rice straw, animal and green manure and to evaluate the compost quality. A secondary objective was to minimize possible groundwater pollution with nitrate nitrogen and phosphate and high levels of BOD and COD resulting from direct dumping of straw to produce compost. 


\section{METHODOLOGY}

\section{Experimental site}

Performances of the lysimeter, estimation of nitrate and phosphate leaching, compost quality were conducted at Meewathura University Farm, Department of Agricultural Engineering, University of Peradeniya. Laboratory testing was carried out at the Agricultural Biotechnology Center and at the Department of Agricultural Engineering, University of Peradeniya.

\section{Lysimeter}

The bioreactor was designed at the Solid Waste Management Research Unit (SWMRU), of the Department of Agricultural Engineering, University of Peradeniya. It consisted of a lysimeter (Fig. 1), a gas collection system, leachate collection and recirculation systems pressure and settlement measuring systems. A lysimeter constructed previously with an average inner diameter of $122 \mathrm{~cm}$, average depth of $325 \mathrm{~cm}$ and $10 \mathrm{~cm}$ diameter of three sampling ports at a height of $91.5 \mathrm{~cm}, 152.5 \mathrm{~cm}, 213 \mathrm{~cm}$ from the top of the reactor was used as the landfill bioreactor. Inside wall of the reactor was plastered to prevent the gas movement through it. In laying the liner, first a layer of aggregates was placed and leveled. Then a sand layer of 2 inch was applied on top of the aggregate layer. After that a layer of clay was applied up to 4 inch and compressed to two inches. Then a mixture of clay and polythene liner was applied up to 4 inch which was also compressed to 2 inch thickness. Then second clay layer was placed as explained above. To prevent the boundary effect, a sealant was applied around the lysimeter, above the sand layer. The sealant was prepared using clay, cement, lime and water at the ratio of 9:3:3:4. This waste polythene and compacted clay liner named 'Clay-Polythene-Clay liner' developed by Gunarathna et al. (2007) was used for the study. For purifying the leachate the permeability of these liners is important. Thus, the permeability was measured at two different heights. A constant water head was maintained until the measurement of permeability reached steady state. In this system, recirculation was done at two different heights such that the recirculation pipes were placed on top of and in the middle of the lysimeter. Leachate was re-circulated through the middle pipe and the rainfall water and leachate were added from the top pipe. Valves were used to change the leachate recirculation pathway. The top pipe was placed $3 \mathrm{~m}$ above from the top of the clay-polythene-clay liner and the middle one was placed $1.5 \mathrm{~m}$ above the liner.

\section{Feeding of the lysimeter}

Initially, the leachate collecting pipes were placed and then straw was placed with water and compacted. Straw was placed up to $27 \mathrm{~cm}$ height from the liner and then cow dung $(26 \mathrm{~kg})$ mixed with water at 1:1 ratio was applied as a $3 \mathrm{~cm}$ thick layer. Then wetted straw was placed and compacted. Altogether $431 \mathrm{~kg}$ of straw and water were added to compact the straw at 1:1 ratio. Straw was filled up to the top of the leachate recirculation pipe and then green materials $(32 \mathrm{~kg}$ ) were added and subsequently the top recirculation pipe was placed. Then the settlement measuring rod was placed and lysimeter was closed with a cap. 


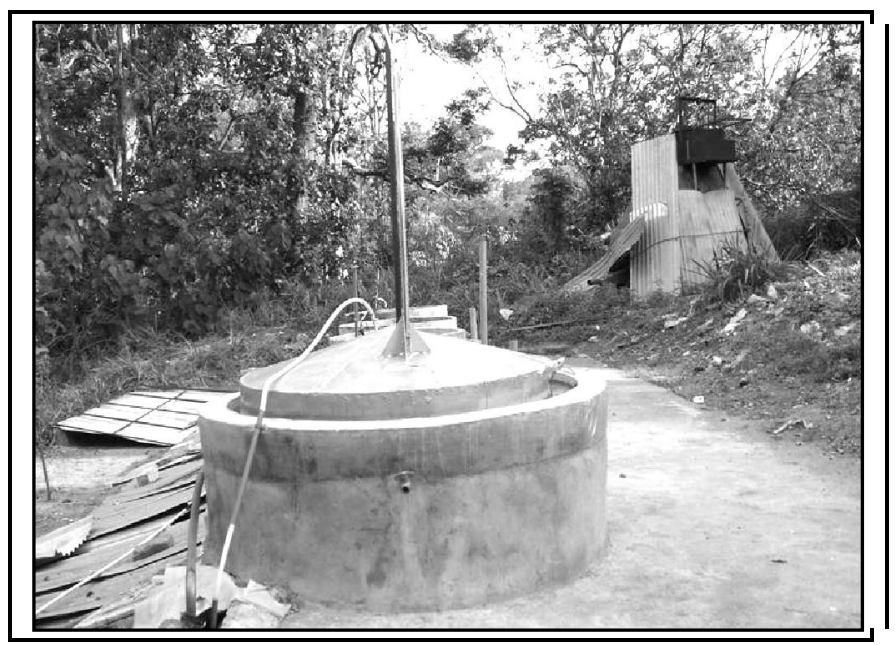

Fig. 1. The Lysimeter at Meewatura farm

\section{Chemical and microbial analysis}

The leachate and permeate samples from the lysimeter were taken and analyzed once a week. Composted material was taken out of the lysimeter after 250 days and physical, nutrients, biological and microbiological parameters of compost were evaluated as listed in Table 1.

Table 1. Chemical analysis for leachate, leak and compost

\begin{tabular}{|c|c|c|}
\hline Analytical Parameter & Method & Instrument used \\
\hline$\overline{\mathrm{pH}}$ & $\mathrm{pH}$ meter & Lonalyzer (model 407) \\
\hline Biological Oxygen Demand (BOD) & Winkler Procedure & n.a. \\
\hline Chemical Oxygen Demand (COD) & Reactor Digestion method & HACH DR/890 colorimeter \\
\hline Heavy metals & $\begin{array}{l}\text { Atomic Absorption } \\
\text { spectrophotometer }\end{array}$ & GBC933, Australia \\
\hline Nitrate nitrogen & Markus et al. (1985) & n.a. \\
\hline Phosphate & Olsen P method & n.a. \\
\hline Potassium & Flame Photometer & Janeway PFP 7 Photometer \\
\hline Organic matter & Walkey - Black method & n.a. \\
\hline
\end{tabular}

n.a. Not applicable

\section{Results and Discussion}

\section{Performance of the lysimeter}

The combination of the clay - polythene - clay liners is the important part for the purification system where the mixture of clay and polythene may have potential to reduce ground water pollution (Gunarathna et al., 2007). To have the best effect of purification, the permeability of the composite liner is important. The permeability values were very low, permeating through the liner $\left(5.910-{ }^{7} \mathrm{~cm} / \mathrm{s}\right.$ at $6 \mathrm{~h}$ at a water height of $\left.60 \mathrm{~cm}\right)$. Recirculation of the leachate helped promoting the waste settlement by allowing the leaching of hydrolyzed wastes into the bottom part of the lysimeter. The leaching of hydrolyzed wastes 
created high porosity within the waste layer and the settlement took place once leachate had been drained out from the lysimeter.

\section{Quantity and general composition of leachate}

Leachate is a significant component in landfill bioreactor affecting the degradation of waste by enhancing favorable conditions for microbial growth. In the lysimeter simulation of the paddy straw landfill bioreactor, anaerobic conditions prevailed. The quantity of leachate in the lysimeter stimulated anaerobic conditions. Inevitably, the amount of leachate in the reactor had increased the hydrolysis reactions. This increase in hydrolysis caused a decrease in $\mathrm{pH}$ thus affected the gas production. Initially, water is a good medium to compress straw, thus, $1704 \mathrm{~L}$ of water were added to the lysimeter, which gave a $2.3 \mathrm{~m}$ leachate head above the liner. Furthermore, to increase the $\mathrm{pH}$ from the 5.1 to $5.4,5 \mathrm{~L}$ of fresh water was added while $2 \mathrm{~L}$ of leachate were removed. The $\mathrm{pH}$ values and Electrical conductivity (EC) of leachate varied with time and ranged from 5.1-7.25 and 2.24-5.62 respectively. Both Total Dissolved Solid (TDS) and EC varied in a similar manner in the leachate and permeate.

\section{Variation of $\mathrm{BOD}_{5}$ and $\mathrm{COD}$}

Figure 2 shows the variation of the $\mathrm{BOD}_{5}$ and $\mathrm{COD}$ in the reactor. Biochemical Oxygen Demand notably indicates how much of dissolved oxygen can be used by microorganisms in the biological oxidation of organic matter during a specific duration (five days as the standard period) (Mata-Alvarez, 2003). Biochemical Oxygen Demand increased during the first 14 days which gradually decreased subsequently. This could be attributed to the $\mathrm{pH}$ variation and microbial activity in the leachate. $\mathrm{BOD}_{5}$ is the measure of biodegradable organic mass of leachate and that indicates the maturity of the landfill which typically decreases with time (Qasim and Chiang, 1994). They have reported that $\mathrm{BOD}_{5}$ value of municipal solid waste landfill leachate ranged from 3.9-57000 mg L $\mathrm{L}^{-1}$. The $\mathrm{BOD}_{5}$ values of this leachate varied with time which ranged from 1800 to $10980 \mathrm{mg} \mathrm{L}^{-1}$. This may be due to slow release and hydrolysis of organic matter from straw into the leachate. Lack of recirculation might also have contributed to reducing the anaerobic process. COD represents the amount of oxygen required to completely oxidize the organic waste constituents chemically to inorganic end products. The COD values varied from 3300 to $18600 \mathrm{mgL}^{-1}$.

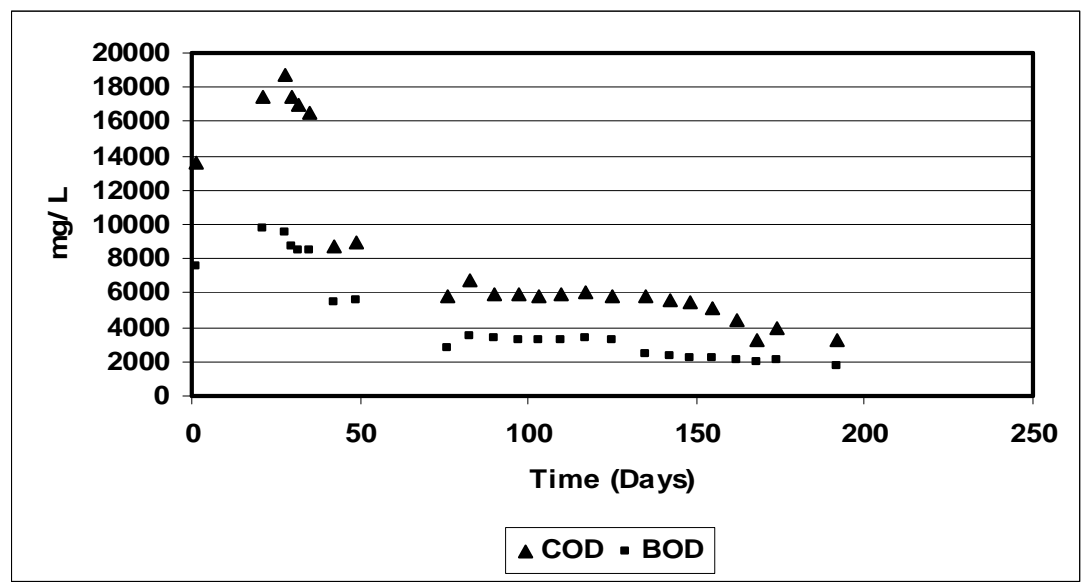

Fig. 2. Variation of BOD and COD in leachate 


\section{Nitrate nitrogen $\left(\mathrm{NO}_{3}{ }^{-} \mathrm{N}\right)$ and Phosphate $\left(\mathrm{PO}_{4}{ }^{-}\right)$in the leachate and leak}

Microbial decomposition of organic carbon influences on many processes of the nitrogen cycle. With time, nitrogen concentration decreased due to microbial utilization of nitrate compounds and denitrifying as ammonia gas (Wu et al., 2006). $\mathrm{NO}_{3}{ }^{-} \mathrm{N}$ of the leachate increased to $600 \mathrm{mg} \mathrm{L}^{-1}$ during the first 35 days and decreased gradually to $216 \mathrm{mg} \mathrm{L}^{-1}$ and again increased. Phosphate content of the leachate increased to $49.62 \mathrm{mg} \mathrm{L}^{-1}$ during the first 14 days and decreased gradually to $5.02 \mathrm{mg} \mathrm{L}^{-1}$. Nitrates are the primary contaminant that leaches into groundwater. Nitrate contamination of drinking water supply restricts the oxygen in the bloodstream in infants under the age of 6 months, causing methemoglobinemia (blue baby syndrome) thus, infants and pregnant women are at a great risk. The United States Environmental Protection Agency (USEPA, 2005) has set a maximum contaminant level of $10 \mathrm{mg} / \mathrm{L}$ for $\mathrm{NO}_{3}-\mathrm{N}$ in public water supplies. Phosphorus transported from agricultural lands to surface water can promote eutrophication, which is one of the leading water quality issues in lakes and reservoirs. It refers to an abnormally high growth of algae and aquatic weeds in surface waters. As organic material decays, natural oxygen levels decline, which leads to changes in fish population or fish deaths. Other common problems associated with eutrophied water bodies include less desirable or restricted recreational use, unpalatable drinking water, and increased difficulty and cost of drinking water treatment. Eutrophic surface waters may also experience massive blooms of cyanobacteria, which potentially pose health hazards to humans and leads to death of livestock (Brady, 2002). Current recommendations of USEPA, (2005) suggest that total $\mathrm{P}$ should not exceed $0.05 \mathrm{mg} / \mathrm{L}$ in a stream at a point where it enters a lake or reservoir and $0.1 \mathrm{mg} / \mathrm{L}$ in streams that do not discharge directly into lakes or reservoirs. After 200 days of operation, $\mathrm{NO}_{3}-\mathrm{N}$ and $\mathrm{PO}^{4}-\mathrm{P}$ content of permeate were $1.23 \mathrm{mg} / \mathrm{L}$ and $0.03 \mathrm{mg} / \mathrm{L}$, respectively. Combination of the claypolythene-clay liners are important for that reduction of $\mathrm{NO}_{3}-\mathrm{N}$ and $\mathrm{PO}^{4}-\mathrm{P}$ content of permeate (Figures 3 (a) and (b)). In reality, the permeate enters soil without beingf collected as observed in the lysimeter. Therefore, on average deep percolation, it would have met the discharge standards as expected from natural attenuation.

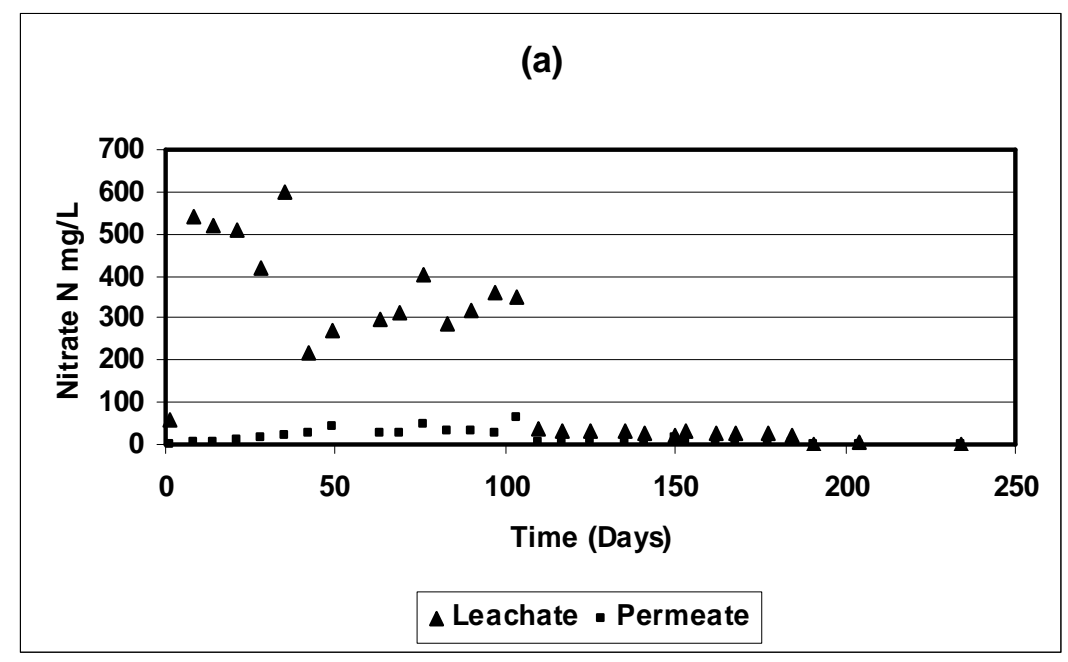




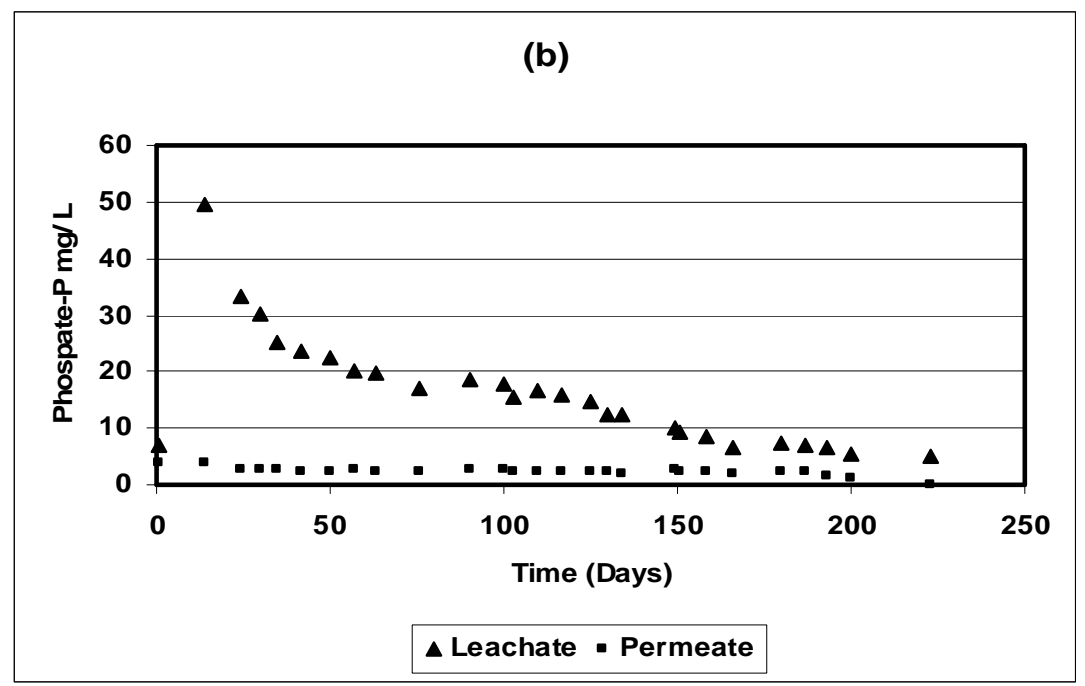

Fig. 3. Variation of nitrate nitrogen (a) and phosphate (b) in leachate and permeate

\section{Evaluation of the quality of the compost}

Maintaining the correct carbon to nitrogen ratio $(\mathrm{C} / \mathrm{N})$ is important for production of good quality compost. Initial $\mathrm{C} / \mathrm{N}$ ratios of rice straw, gliricidia and cow dung were 45,18 and 10.5, respectively. Composting is usually successful when the mixture of organic material consists of 20-40 parts of carbon to 1 part of nitrogen. Compost is considered substitutes for chemical fertilizers. Compost amendments increase cation exchange capacity, buffering capacity, chelating capacity, soil aggregation, aggregate stability, water holding capacity, soil porosity, water infiltration, water percolation, nutrient availability, and earthworm population. Further they lead to decreased soil crusting, bulk density, and plant pathogens. In addition, application of compost alleviates acidic and alkaline conditions stimulating beneficial microorganisms to produce polysaccharides and/or antibiotics (Brady, 2002). In this study, composted material was taken out of the lysimeter after 250 days and physical, nutrients, biological and microbiological parameters of compost were evaluated. Table 2 shows the characteristics of resulting compost and Sri Lanka Standards for the compost.

\section{CONCLUSIONS}

The permeability of the leachate was very less that created conditions for natural attenuation over the entire period of 200 days. The nitrate nitrogen and phosphate of permeate were less than permissible limits. . The BOD and COD increased during the first 14 days and they gradually decreased. The BOD values of leachate varied with time and it can be considered to be relatively high in relation high polluting municipal solid wastes. The ratio of BOD/COD indicates that biodegradation of leachate was high. The quality of the compost tallied with the SLS guidelines. The study shows that there is a high potential of producing compost from landfill bioreactor using rice straw. It also reveals that the groundwater pollution resulting from direct discharge of organic matter can significantly be mitigated. A straw based landfill bioreactor 'test cell' is the future focus of research 
Table 2. Characteristics of mature compost and Sri Lanka standards (SLS) for the Compost

\begin{tabular}{|c|c|c|}
\hline Characteristics & Compost & SLS specifications \\
\hline \multicolumn{3}{|l|}{$\begin{array}{l}\text { Physical } \\
\text { requirements }\end{array}$} \\
\hline Colour & gray to dark black & brown/gray to dark black \\
\hline Moisture content $\%$ & 22.69 & material shall not contain more than $25 \%$ \\
\hline Odour & Earthy smell & not have unpleasant odour \\
\hline Particle size & $1.02 \%$ inert & material shall not leave residue more than $2 \%$ \\
\hline Sand content & $9.55 \%$ & material shall not contain more than $10 \%$ \\
\hline \multicolumn{3}{|l|}{$\begin{array}{l}\text { Nutrient } \\
\text { requirements }\end{array}$} \\
\hline $\mathrm{pH}(1$ to 2.5$)$ & 6.4 & $6.5-8.5$ \\
\hline Organic carbon $\%$ & 23.76 & 20 \\
\hline Total Nitrogen $\%$ & 0.98 & 1.0 \\
\hline Phosphorous \% & 0.6 & 0.5 \\
\hline Potassium \% & 1.32 & 1.0 \\
\hline $\begin{array}{l}\text { Carbon to Nitrogen } \\
\text { ratio }\end{array}$ & 14.85 & $10-25$ \\
\hline $\begin{array}{l}\text { Cadmium ppm } \\
(\mathrm{m} / \mathrm{m})\end{array}$ & 0.04 & 10 \\
\hline $\begin{array}{l}\text { Chromium ppm } \\
(\mathrm{m} / \mathrm{m})\end{array}$ & 0.38 & 1000 \\
\hline Copper ppm (m/m) & 0.28 & 400 \\
\hline Lead ppm $(\mathrm{m} / \mathrm{m})$ & 1.32 & 250 \\
\hline Nickel ppm (m/m) & 0.47 & 100 \\
\hline Zinc ppm (m/m) & 2.74 & 1000 \\
\hline \multicolumn{3}{|l|}{$\begin{array}{l}\text { Biological } \\
\text { requirements }\end{array}$} \\
\hline $\begin{array}{l}\text { Viable } \quad \text { weed } \\
\text { seeds } / \mathrm{m}^{2}\end{array}$ & 8 & 16 \\
\hline \multicolumn{3}{|l|}{$\begin{array}{l}\text { Microbiological } \\
\text { requirements }\end{array}$} \\
\hline $\begin{array}{l}\text { Faecal coliforms } / g \\
\text { material }\end{array}$ & Free & Free \\
\hline $\begin{array}{l}\text { Salmonella } / 25 \mathrm{~g} \\
\text { material }\end{array}$ & Free & Free \\
\hline
\end{tabular}

Source: Sri Lanka Standards Institution (2003)

\section{REFERENCES}

Brady, N.C. (2002). The Nature and Properties of Soils, $10^{\text {th }}$ ed. Prentice-Hall of India Private Limited, New Delhi, India pp. 517-546.

Champaign, E.T., Bet, K.L., Vinyard, B.T., Mc Clung, A.M., Barton, F.E., Moldenhauer, K., Linscombe, S. and Mc Kenzie, K. (1999). Correlation between cooked rice texture and rapid visco analysis measurements, Cereal Chem. 76, 764-771. 
Department of Census and Statistics (2008).http://www.statistics.gov.lk/agriculture.

Gunarathna H.A.Y.R., Kapukotuwa A.S.B., Karunarathna A.K. and Basnayake B.F.A. (2007). Construction and evaluation of a low cost, wasted polyethylene based liner for small landfills. In: Proceedings of International Conference on Solid Waste Management, Chennai, India. 5-7.

Markus, D.K. McCinn, J.P. and Buccafuri, A.F. (1985). Automated analysis of nitrite, nitrate and ammonia nitrogen in soils. J. Soil Sci. Soc. of Am. 479, 1208-1215.

Mata-Alvarez, J.(2003). Bioremethanization of the organic fraction of municipal solid waste. IWA publishing, Cornwall, UK. pp 1-17.

Panabokke, C.R. (1996). Soils and Agro-Ecological Environments of Sri Lanka Natural Resources, Energy and Science Authority of Sir Lanka 2, 220.

Qasim, S.R., Chiang, W. (1994). Sanitary Landfill Leachate. Generation Control and Treatment. Tecnomic Publication.

USEPA (2005) U.S. Environmental Protection Agency Nonpoint Source Control Branch (4503T) 1200 Pennsylvania Avenue, NW Washington, DC 20460 epa.gov/nps

Warith, M., Li, X. and Jin, H. (2005).Bioreactor landfills: State-of-the-Art-Review. Envtl. J. for Engi. 10(1): 1-14.

Wickramasinghe, W. M.A.D.B. and Wijewardena, J.D.H.(2000). Soil fertility management and integrated plant nutrition systems in rice cultivation. Rice Congress, Department of Agriculture, Peradeniya, Sri Lanka. 25-140.

Wu, D., Quan, X., Zhang, Y. and Zhao, Y.(2006). Long-term operation of a compost-based biofilter for biological removal of $n$-butyl acetate, $p$-xylene and ammonia gas from an air stream. Bioche. Engi. J. 32(2): 84-92. 